\title{
The Meaning of Private Space as Media Representation in Rans Entertainment Vlog
}

\author{
Welly Wirman \\ Department of Communication Science \\ Universitas Riau \\ Pekanbaru, Indonesia \\ welly.wirman@lecturer.unri.ac.id
}

\author{
Genny Gustina Sari \\ Department of Communication Science \\ Universitas Riau \\ Pekanbaru, Indonesia \\ genny.gustina@lecturer.unri.ac.id
}

\author{
Gun Faisal \\ Department of Architecture \\ Universitas Riau \\ Pekanbaru, Indonesia \\ https://orcid.org/0000-0002-6580-1701
}

\begin{abstract}
The development of information technology today brings significant life changes. The emergence of a new profession that has not been taken into account has made Vlog a medium for entertainment and new information for the public. The content displayed to the public also varies, including vlogger activity in private spaces such as bathrooms and bedrooms. This can be seen from the Rans Entertainment vlog, which displays activities made into content with the arrangement of their personal space. Private spaces that were once taboo to be displayed in public are now commonplace, especially in this digital era. This paper describes the meaning of public and private space in the digital world by looking at the representation of private space through the Rans Entertainment vlog. The results show that for artists, the boundaries between public and private spaces are getting wider. The priority of content interests makes the meaning and function of public space wider. Even though it is considered taboo, showing the private space of these celebrities has benefited from a social and economic side. Private space is no longer seen from its functions and uses, but it captures their daily activities when the camera is not there.
\end{abstract}

Keywords - Representation, Private Room, Vlog, Meaning, Media

\section{INTRODUCTION}

The internet has connected people worldwide, impacting everyday life from games, work, and entertainment to political affairs between countries. Social media forms a relationship between humans and physical space online. The new community was formed complete with various attributes in the physical public space and the online public space. We then get to know the terms network, community, public space, a network that connects oneself to the broader public. Social media creates distributed communities where knowledge-sharing activities occur and recognize each individual's collective awareness [1].

Talking about the public sphere, we cannot escape the concept of the public sphere and public space from
Habermas, who argues that under certain conditions, the media plays a role as a forum that facilitates discourse in the public space. The public space itself represents a network for communicating information from various points of view. Habermas took the example of the increasing role of the media in the 18th century as a catalyst that led to the emergence of the public space. The public sphere is not only the realm of political communication but also free from state censorship and private ownership [2]. However, Habermas' version of the definition of public space seems rigid because it considers the public space only as an arena where everyone is allowed to participate in that arena. This statement is only aimed at the bourgeoisie as if the public sphere belongs only to the bourgeoisie. The public sphere is described in three crucial areas, namely; 1) the public space as an arena that allows the communication process to occur between communities, 2) the public itself becomes part of the public space which means that the public is the main actor in the formation of meaning and 3) if the public is the main actor then the public space acts as the agent in charge convey public aspirations [3].

Social media as a new public space presents an exciting side to be seen, no longer talking about social class. The middle class also uses social media such as YouTube. Social media is no longer widely used as a tool for rulers but is also used as a medium for people to show their existence and self-appreciation, socialize and communicate, and a new profession. Wasisto Raharjo Jati, in his writing Cyberspace, Internet and New Public Spaces: Indonesian Middle-Class Political Online Activism, presents Habermas' public space with public space as Cyberspace [4]. Unfortunately, Jati seems to separate the Habermas version of the concept of public space from that of public space in the context of Cyberspace, even though most of what is displayed in social media is an activity in the physical public space. 
TABLE I. COMPARISON OF Public SPACE AND Cyberspace

\begin{tabular}{|c|c|c|c|}
\hline \multirow[b]{2}{*}{ No } & \multicolumn{3}{|c|}{ Comparison } \\
\hline & $\begin{array}{l}\text { Habermas Public } \\
\text { Space Parameters }\end{array}$ & Public Space & Cyberspace \\
\hline 1 & $\begin{array}{l}\text { Actor supporting } \\
\text { public space }\end{array}$ & The bourgeoisie & Netizen \\
\hline 2 & Citizenship & $\begin{array}{l}\text { Based on the } \\
\text { identity of ius } \\
\text { sanguinis } \\
\text { (hereditary } \\
\text { principle) and ius } \\
\text { soli (birth } \\
\text { principle) }\end{array}$ & $\begin{array}{c}\text { Based on } \\
\text { common issues } \\
\text { and interests }\end{array}$ \\
\hline 3 & $\begin{array}{l}\text { Forms of Public } \\
\text { Space }\end{array}$ & $\begin{array}{l}\text { Public facilities } \\
\text { such as cafes, } \\
\text { restaurants, } \\
\text { campuses, etc. }\end{array}$ & Social media \\
\hline 4 & $\begin{array}{ll}\text { Public } & \text { Space } \\
\text { Functions } & \\
\end{array}$ & $\begin{array}{l}\text { Communication } \\
\text { and Advocacy }\end{array}$ & $\begin{array}{c}\text { Leisure and } \\
\text { pleasure }\end{array}$ \\
\hline 5 & $\begin{array}{l}\text { Reach of Public } \\
\text { Spaces }\end{array}$ & $\begin{array}{l}\text { Within one } \\
\text { country }\end{array}$ & Cross country \\
\hline
\end{tabular}

The formulation of public space is not as simple as Habermas' thought. If the conditions specified for public space are face-to-face and spatial distance, online public space certainly cannot be categorized as public space. On the other hand, if the public space is intended to reach a wider audience and without boundaries, Habermas public space concept cannot be categorized as a public space [1]. In their writings, Jose Van Dijck and Thomas Poell explain that social media transforms the concept of public space, which refers to the idea of sharing and providing support that shapes their own social space based on classless equality. It is also said that social media platforms have succeeded in mediating the concept of public space and between public space and private space in people's online traffic [5].
Manuel Castells emphasized that constructing a new public domain in a networked society takes place by establishing communication protocols between completely different communication processes [6]. In this study, the author will focus on the social media Youtube. Jean Burgess and Joshua Green [7] added that Youtube is a public cultural space that encourages encounters with cultural differences and political development across belief systems and people's identities. The split between what is considered the private sphere and the public sphere occurs due to the differentiation of modern society in various fields such as economy, society, family environment, and intimacy. Nicholas Gamham defines the duality of personal and public differences.

TABLE II. DuAlity of PUBlic AND PRIVATE DifFERENCES

\begin{tabular}{|l|l|l|}
\hline No & \multicolumn{1}{|c|}{ Private } & \multicolumn{1}{c|}{ Public } \\
\hline 1 & Individual & Social \\
\hline 2 & Family & Public \\
\hline 3 & Economy & Government \\
\hline 4 & Civil Society & Country \\
\hline 5 & World of Life & World of Systems \\
\hline 6 & Agent / Action & Structure \\
\hline 7 & Everyday life & Structure / system / power \\
\hline 8 & Natural & Culture \\
\hline 9 & Feeling & Reason \\
\hline 10 & Freedom & Power \\
\hline 11 & Art & science \\
\hline 12 & Personal & Political \\
\hline 13 & Positive Freedom & Negative Freedom \\
\hline
\end{tabular}

Hannah Arend [8] states a relevant difference between the private sphere and the public sphere because it relates to what can be displayed in public and what must be hidden. Privacy is related to what should 
be seen or allowed to be shown and what should be hidden. If we refer to Arendt and Gamham's private and public spaces concepts, we should agree that everyday life, especially intimate matters, falls into the category of private sphere or space.

Youtube, as one of the most widely used social media by the world community, with 2 million accounts recorded in 2020, has now proven that the internet is an essential part of everyday life wherein 2020 internet users in the world reach 4.5 billion or the equivalent of $60 \%$ of the world's population has used the internet [9]. Youtube, side by side with Facebook, is the most loved social media. This research focuses on the social media Youtube because of its ability to present audio and visuals as a medium for users to "broadcast" themselves in public spaces. This study chose the YouTube Rans Entertainment Vlog account owned by artists Raffi Ahmad and Nagita Slavina because it has consistently uploaded their daily lives since 2015 . In addition, this account is recorded as an account with 20.6 billion subscribers and the most significant income earner, which is equivalent to IDR 576, 29 million - Rp. 9.22 billion (exchange rate of Rp. 14,300 per US dollar) in May 2021[10].

Public space and private space represented on social media show controlled and commodified spectacle and illusion. The communication process is rooted in the spatial nature of the public space, which provides details about existence (space and time attributes) and references (marking of places). The practice of everyday life is elaborated into images and videos to produce direct interaction from other people without state control in it [11][12]. Patricia G Lange [13] explained that Youtube users use technical and symbolic mechanisms to describe social networks that are not wholly public and not completely private. Youtube users are given control to determine and create public and private interactions in optimizing their social networking sites. Manipulation of public space and private space is a way for them to protect the level of privacy amid the public scrutiny involved, meaning that what they display looks as if it is private, but for them, the private space has certain levels and layers.

Using the observation method, the author traces the Youtube Rans Entertainment account to see how they represent their personal space on YouTube and what effect the disclosure of personal space on YouTube social media has on audience response, in this case, seen from the number of viewers and comments given. The data collected will be analyzed using a descriptive qualitative method that describes the findings in a narrative form. The author also refers to Habermas' concept of the public sphere and Gamham's dualism of private space and public space to see the meaning of space for artists on Youtube social media.

\section{RESULTS AND DISCUSSION}

\section{A. Personal Space Disclosure on Rans Entertainment Vlogs}

Youtube Rans Entertainment was first uploaded on December 29, 2015, and until May 26, 2021, has uploaded $2.1 \mathrm{~K}$ videos, always consistently telling the activities of their daily life. In the actual Rans Entertainment account, if we refer to the Habermas concept, it can be assumed that most of the activities are carried out in private rooms such as the dining table, living room, bedroom, the bathroom. The themes also raised Most of them to tell about their daily activities, starting from waking up, work, hobbies, cooking activities, makeup, vacations, to vent sessions (outpouring). However, this study will only show a few images that capture the disclosure of their personal space, which is categorized as intimate.

The disclosure of personal space and daily life has succeeded in attracting audience interest. The Rans Entertainment account and several other vloggers account also choose to reveal their personal space and daily activities to be shared with the audience. The results of the author's observation of the Rans Entertainment account show that disclosure of personal space and themes that are intimate (very personal) gets more responses than the post about children's education in the video "Si AA." The disclosure of private spaces such as the bedrooms of Raffi Ahmad and Nagita Slavina shows that the boundaries between private and public things in their posts are biased. One post, for example, shows the couple's morning activities when they wake up from their sleep, something that is considered taboo for Indonesian culture. Private life has become a salable commodity to be sold to the public and has changed the way people perceive social values and relationships, a very private life, such as husband and wife quarrels, is no longer taboo to expose commercialized as the Lambe Turah account does [14]. 

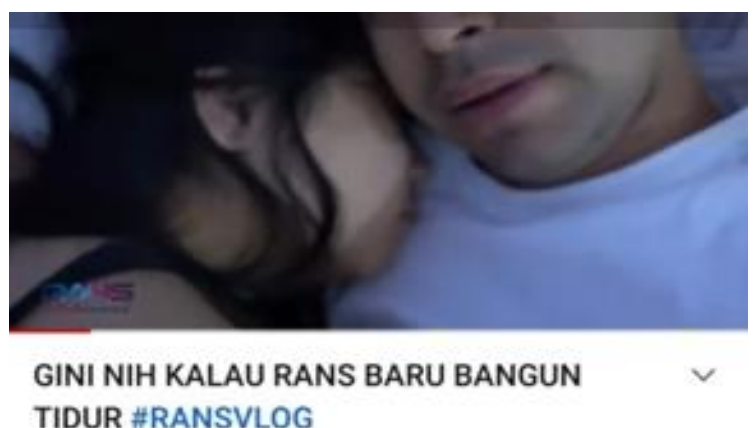

$2.2 \mathrm{M}$ views -3 years ago

\begin{tabular}{|c|c|c|c|c|}
\hline $\mathbb{B}$ & $\nabla$ & $\Rightarrow$ & & $\boxplus$ \\
\hline $37 \mathrm{~K}$ & 672 & Share & Download & Save \\
\hline & $\begin{array}{l}\text { Entert } \\
\text { ubscrit }\end{array}$ & & & 3SCRIBE \\
\hline
\end{tabular}

Fig. 1. Disclosure of Personal Space (Bedroom)

The bedroom, if we pull in the concept of Habermas or Gamham, is categorized as a private space. In fact, it is commodified by this artist couple to be then displayed on public social media. A post with a private room setting, namely the bedroom becomes a vlog with the highest number of viewers, $22 \mathrm{M}$ with the video title "Prank papa Raffi- All around papa there is rambutan." posted on March 6, 2019, shows the audience's immense attention to the disclosure of the artist couple's personal space.

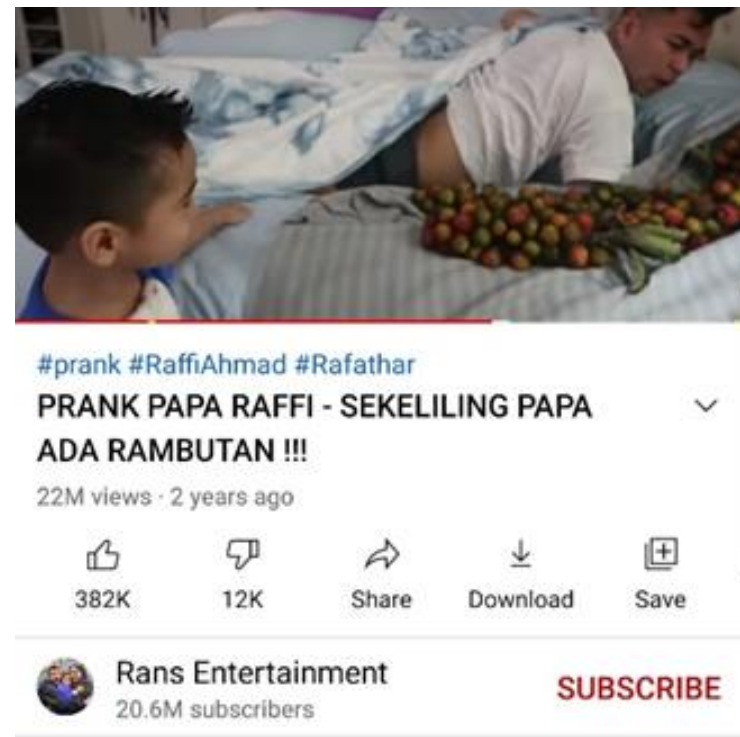

Fig. 2. Disclosure of Personal Space with the Most Viewers

The disclosure of personal space on social media, in this case, Youtube, shows the efforts of Raffi Ahmad and Nagita Slavina to satisfy the curiosity of their fans about what this couple does every day, how to decorate their homes and rooms, and to find out their clothing tastes and collections of idol artists. The results of the observation that the author has done show that the greater the number of viewers in a post, the bigger the chance for Raffi Ahmad and Nagita Slavina to open themselves, especially their private space, to the public. One example of the disclosure of private space and private activities to public spaces is bathing together in one of the salons or body treatments.
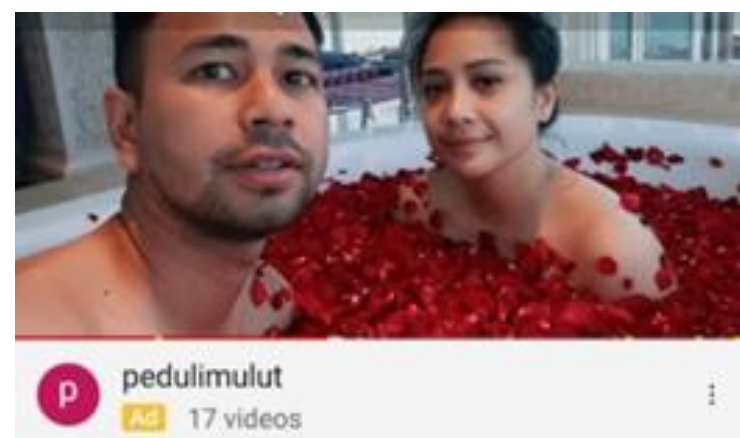

\section{MANJAIN DIRI DI KOLAM MAWAR DAN TREATMENT BERLIAN! TAPI BETE LAGI}

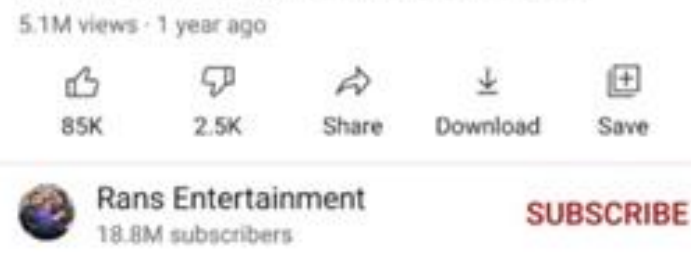

Fig. 3. Disclosure of Personal Space and Personal Activities

The disclosure of personal activities that are in the cultural fabric and habits of the Indonesian people in the public space of social media shows that the public response is a reference that makes eastern values sidelined. The high public interest in knowing and following the activities of their idol artists has made the boundaries between public space and private space on social media, in this case, YouTube, blurred. Public space and private space functions become biased because private activities carried out in private rooms are displayed in public spaces.

Analyzing the Vlog contents on the Rans Entertainment account, the author saw that almost all of the vlogs talked about the daily activities of Raffi Ahmad and his family. The authors see that the account owner's placement and meaning of public and private space make the boundary between public and private space blurred. Even though private space posted for ordinary people is considered taboo or before social media and the internet became a public need, we also need to see that the presence of the internet and social media is also responsible for the refinement of the boundaries of public space and private space on social media. There are at least several reasons why the boundaries between private space and public space are blurred, including: 
- Economic interests. Media capitalization makes users elaborate and commodifies their lives to be presented to the broader community. In this case, both Raffi Ahmad and his family can be compared to food served to meet the needs and quench public thirst. Raffi Ahmad and his family are products that provide themselves to be exploited and consumed passively by the public. In the end, this brings significant benefits to the capitalists who control the economic and political markets of the world, although it cannot be denied that through the disclosure of their personal lives, they also get much profit.

- Self-existence. The disclosure of daily life to the public is a manifestation of the perpetrator's self-existence. Display lifestyle, styles, and habits invite the wider community to rate and give credit to vloggers. The nickname Sultan Andara for Raffi Ahmad can represent a wealthy idol figure like the posts displayed on their accounts. Although Raffi Ahmad disagrees with this, he also does not deny this proves that the representation of his personal life on the Rans Entertainment vlog brings financial and nonfinancial benefits. In Vlog, Rans Entertainment brings financial and non-financial benefits.

\section{B. Blurred Boundaries of Social Media and Real Life Space}

The blurred boundaries between personal space and public space on social media cannot be separated from the meaning produced from the representation of the life of Raffi Ahmad and his family on their Youtube account. Disclosure of personal space such as bedrooms and bathrooms on social media is considered normal for them. What was then considered private becomes smaller and smaller. For example, activities carried out in the bedroom are considered to be consumed by the public so that the bedroom that Habermas or Gamham previously considered as a private space in social media becomes a public space. Activities that were only allowed to be carried out in a private room, such as sleeping or bathing, are considered activities that can be displayed in public spaces.

The question then is whether the concept of Habermas' public sphere and Gamham's dualism of private space and private space does not apply to social media? To answer this question, we must return to the concept itself. Instead of calling the boundaries between private space and public space disappearing or blurred, the authors prefer to call it an extension of the concept and boundaries of public space. In digital world activities, control is entirely held by the public itself, both by the actors and the audience who enjoy it. The socio-political-economic motives behind the spatial expansion of the public space and the narrowing of the private space cannot be blamed as long as the public agrees. The concepts of Hebrmas and Gamham did not immediately collapse and were no longer valid for use.
Instead, these concepts became the basis for the expansion of the public space in social media.

Talking about the appropriate or inappropriate disclosure of personal space on social media refers to collective agreements that occur within the social networks that are formed. Raffi Ahmad and Nagita Slavina, together with their fans, become a social network with boundaries considered reasonable for them, maybe not for the public outside the network. The personal space that is no longer personal, along with the activities usually carried out in that space, eventually adjusts to the needs and desires of the fans/audience.

\section{CONCLUSION}

Disclosure of personal space in the public sphere on Youtube social media is not unusual lately. The daily life activities of the artists are becoming a new menu that is very popular with the audience. Activities that occur in private spaces have been commodified and elaborated so that they are deemed appropriate to be displayed in the public domain. The author sees the disclosure of private space in the public sphere as motivated by social and economic motives. Selfexistence and a promising economic improvement led Raffi Ahmad and his family to make themselves available to be watched, consumed, and enjoyed by the public. The author also sees an extension of the meaning of the concept of public space displayed on social media. The expansion of public space and the activities therein has a consequence of narrowing the private space for the actors who play it. Both Raffi Ahmad and other vloggers are certainly aware of the disclosure of their personal space and personal activities displayed in the public social media space, as long as the social networks that are formed agree and consider it reasonable, as long as the personal space and personal activities of the artist or vlogger can be enjoyed. audience.

\section{ACKNOWLEDGMENT}

The author would like to thank many parties who helped in the completion of this research, especially the leadership of the University of Riau (Rector), the Dean of the Faculty of Social and Political Sciences and the Institute for Research and Community Service at the University of Riau (LPPM-UNRI).

\section{REFERENCES}

[1] T. Tierney, The Public Space of Social Media: Connected Cultures of the Network Society. Taylor $1 \&$ Francis, 2013.

[2] J. Habermas, Transformasi Struktural Ranah Publik; Penyelidikan Terhadap Kategori Masyarakat Borjuis. cambridge: MIT Press, 1991.

[3] D. Schuler and P. Day, Shaping the Network Society: The New Role of Civil Society in Cyberspace. MIT Press, 2003.

[4] W. R. Jati, "Cyberspace, Internet, dan Ruang Publik Baru: Aktivisme Online Politik Kelas Menengah Indonesia," J. Pemikir. Sosiol., vol. 3, no. 1, pp. 25-35, 2016. 
[5] J. Van Dijck and T. Poell, "Social media and the transformation of public space," Soc. Media+ Soc., vol. 1, no. 2, p. 2056305115622482, 2015, doi: https://doi.org/10.1177/2056305115622482.

[6] M. Castells, Networks of Outrage and Hope: Social Movements in the Internet Age. Wiley, 2015.

[7] C. Fuchs, "Social media and the public sphere," tripleC Commun. Capital. I\& Crit. Open Access J. a Glob. Sustain. Inf. Soc., vol. 12, no. 1, pp. 57-101, 2014, doi: https://doi.org/10.31269/triplec.v12i1.552.

[8] H. Arendt, M. Canovan, and D. Allen, The Human Condition: Second Edition. University of Chicago Press, 1958.

[9] B. Ramadhan, "Ini Data Pengguna Internet di Seluruh Dunia Tahun 2020," TEKNOIA, 2020. https://teknoia.com/datapengguna-internet-dunia-ac03abc7476.

[10] S. Baskoro, "Youtuber Indonesia dengan perkiraan penghasilan tertinggi tahun 2021!,” STYLE Kontan.co.id,
2021. https://lifestyle.kontan.co.id/news/ini-5-youtuberindonesia-dengan-penghasilan-tertinggi-tahun-2021?page=all .

[11] M. Manfredini, J. Jung, and A. Hills, "New technologies, social media and spatial representations: Auckland's public space of spectacle and consumption," AASA 2015 Appl. Collab., 2015.

[12] M. J. Walsh and S. A. Baker, "The selfie and the transformation of the public--private distinction," Information, Commun. I\& Soc., vol. 20, no. 8, pp. 1185-1203, 2017.

[13] P. G. Lange, "Publicly private and privately public: Social networking on YouTube," J. Comput. Commun., vol. 13, no. 1, pp. 361-380, 2007.

[14] N. Widyawati, "Komodifikasi Kehidupan Pribadi dan Demokrasi Semu dalam Budaya Digital,” Masy. Indones., vol. 44, no. 1, pp. 47-60, 2019. 